\title{
Could the Fucus Spiralis Algal Extract Prevent the Oxidative Stress in Tetrahymena Pyriformis Model?
}

\author{
Fatiha Grina 1," ${ }^{\mathbb{D}}$, Abdellatif Rahim ${ }^{1 \mathbb{D}}$, Talal Sabraoui ${ }^{1 \mathbb{D}}$, Boubker Nasser ${ }^{1 \mathbb{D}}$, Abderrahman \\ Moujahid 1(D), Rabiaa Eddoha 1(D), Evan Alexander Netherton Marks 2(D), Maryam Benbachir 1(D), \\ Mehmet Öztürk ${ }^{3}$ (D), Abdel Khalid Essamadi ${ }^{1}$ (D) \\ 1 Laboratory of Biochemistry and Neuroscience, Applied Biochemistry and Toxicology Team, Faculty of Sciences and \\ Technology, Hassan 1st University, P.O. Box 577, 26000 Settat, Morocco \\ 2 CT BETA, Universitat de Vic - Universitat Central de Catalunya, Carrer de la Laura 13, 08500 Vic, Spain \\ 3 Faculty of Science, Department of Chemistry, Muğla Sitkı Koçman University, 48121 Kötekli, Muğla Türkiye \\ * Correspondence: f.grina@ uhp.ac.ma; fatihagrina@yahoo.fr;
}

Scopus Author ID 57211752270

Received: 20.07.2020; Revised: 23.08.2020; Accepted: 25.08.2020; Published: 30.08.2020

\begin{abstract}
Algae are well-known to be exceptionally rich sources for biologically active metabolites and have recently gained recognition for their therapeutic applications. This study is designed to assess the phenolic composition of five algae and evaluate their antioxidant and protective effects against hydrogen peroxide $\left(\mathrm{H}_{2} \mathrm{O}_{2}\right)$ induced cytotoxicity in the protozoa Tetrahymena pyriformis. Successive fractionations of five algae using five solvents were performed. Spectrophotometric methods were used to determine the total phenolic and flavonoid contents. The antioxidant capacities of fractions of these five algae were assessed through three in vitro tests (DPPH, ABTS, and FRAP). The active fractions were further evaluated for their ability to attenuate $\mathrm{H}_{2} \mathrm{O}_{2}$ induced toxicity in T. pyriformis. Fucus spiralis has rich phenolic contents from chloroform $\left(\mathrm{CHCl}_{3}\right)$ and ethyl acetate (EtOAc) fractions, averaging $65 \pm 0.90 \mu \mathrm{g}$ GAE$/ \mathrm{mg}$ fraction and 429.81 $\pm 9.36 \mu \mathrm{g}$ GAE $/ \mathrm{mg}$ fraction, respectively. This algae also showed significant FRAP $(261.53 \pm 5.40$ and $117.66 \pm 0.40 \mu \mathrm{g} / \mathrm{mL})$, DPPH (IC50: $49.51 \pm 3.29$ and $55.48 \pm 0.20 \mu \mathrm{g}$ ) and ABTS (IC50: $50.73 \pm 2.62$ and $219.82 \pm 5.47 \mu \mathrm{g} / \mathrm{mL}$ ) results. The treatment with $300 \mu \mathrm{M} \mathrm{H}_{2} \mathrm{O}_{2}$-induced oxidative stress as shown by the significant decrease in the cell viability and the number of cells increases in CAT, SOD, GPx activities, and the levels of GSH and MDA. However, the treatment with EtOAc and $\mathrm{CHCl}_{3}$ fractions from $F$. spiralis appeared to be effective against cytotoxicity and the redox changes induced by $\mathrm{H}_{2} \mathrm{O}_{2}$. The results indicate that $F$. spiralis is a promising source of antioxidant and nutraceutical compounds for pharmaceutical purposes.
\end{abstract}

Keywords: Antioxidant activity; brown algae; Fucus spiralis; oxidative stress; Tetrahymena pyriformis; hydrogen peroxide.

(C) 2020 by the authors. This article is an open-access article distributed under the terms and conditions of the Creative Commons Attribution (CC BY) license (https://creativecommons.org/licenses/by/4.0/).

\section{Introduction}

Oxidative stress may produce excess amounts of free radical species following the exposure of aerobic cells to endogenous and exogenous factors. Reactive oxygen species (ROS) have important roles in the regulation of intracellular signal transduction and physiological adaptation phenomena in normal cells and tissues [1]. However, excessive concentration of ROS may trigger the development of various chronic diseases by impairing the structure of cellular membrane lipids, proteins, and DNA [2-3].

Hydrogen peroxide $\left(\mathrm{H}_{2} \mathrm{O}_{2}\right)$, a relatively weak oxidant reactive oxygen species form ROS, is generated by a variety of intracellular reactions [2]. Physiologically, the low levels of 
endogenous $\mathrm{H}_{2} \mathrm{O}_{2}$ modulate physiological cellular functions [4]. However, high levels of $\mathrm{H}_{2} \mathrm{O}_{2}$, such as observed in inflammatory states, generally cause cellular dysfunction and/or cytotoxicity.

The accumulation of excessive ROS is expected to worsen the oxidative stress and might be implicated in a set of disorder/disease processes, including heart disease, diabetes, liver injury, cancer, neurodegenerative diseases such as Alzheimer's disease, and other agerelated degenerative disorders [5-6]. However, the sensitivity of cells to oxidants is controlled by producing enzymatic antioxidant defense systems, such as glutathione peroxidase (GPx), catalase (CAT) and superoxide dismutase (SOD), non-enzymatic glutathione (GSH), histidinepeptide, or iron-binding proteins [7]. In addition to such defenses, the supplementation of antioxidants can be considered as the alternative method for chelation therapy of free radicals.

Over the past few decades, researchers have pursued efforts to isolate natural bioactive compounds with versatile health benefits, and substantial attention has been focused on a wide array of antioxidants [8]. Marine macroalgae have been widely used in traditional foods since ancient times and are traditionally renowned for their versatile health benefits [9-10]. Several compounds with antioxidative action have been isolated from brown algae, most of them belonging to the phenolic fraction [11-12]. The total phenolic contents and activities of brown algal extracts have been reported [13-14].

Marine macroalgae have long been reported to be rich in unique bioactive compounds that are not found in terrestrial plants, including different proteins such as lectins, phycobiliproteins, peptides, and amino acids [12-15], hormones [16], polyphenols [17-18], polysaccharides [19 -20], and other novel bioactive compounds which might represent a potential to be used in the development of new human health applications [21]. Algae extracts have been described to have many phytochemicals with a range of different activities such as anti-inflammatory effects [22-23], neuroprotective effects [24-25], anti-aging effects [26-27], anti-cancer effects [22], antibacterial activity [28-29], antioxidant effects [30-31] and cardioprotective effects [32].

Our recent studies on the five algae showed that Fucus spiralis has a higher antioxidant activity among the other species [31]. Therefore, the aim of this study is to evaluate the antioxidant activity of five algae from Moroccan coastlines by quantifying of total phenolic and flavonoid contents, 2,2-diphenyl-1-picrylhydrazyl (DPPH), 2,2'-azino-bis (3ethylbenzthiazoline-6-sulphonic acid (ABTS) and by the ferric reducing antioxidant power (FRAP). In this study, Tetrahymena pyriformis, eukaryotic cell, was used as a model that imitates the animal cell, especially mammalian and used widely in toxicology and ecotoxicology [33]. The selected algal fractions were then evaluated for their protective effect against $\mathrm{H}_{2} \mathrm{O}_{2}$-induced stress on Tetrahymena pyriformis cellular antioxidants, metabolic systems, and in particular, their effects on CAT, GPx, SOD, GSH, and malondialdehyde (MDA) levels. The fractions of chloroform $\left(\mathrm{CHCl}_{3}\right)$ and ethyl acetate (EtOAc) of $F$. spiralis were used for the treatment of forced stress induced by $\mathrm{H}_{2} \mathrm{O}_{2}$.

\section{Materials and Methods}

\subsection{Algal materials.}

Alive and fresh samples of algae were collected during the low tide in the middle/lower intertidal areas of a beach from the Atlantic coast, namely Golden Sand Beach (sable d'Or, $33^{\circ} 919677^{\prime} \mathrm{N}$; $\left.6^{\circ} 969531^{\prime} \mathrm{E}\right), 10 \mathrm{~km}$ south of Rabat-Morocco. The investigated algae were 
identified as Bifurcaria bifurcata (Ross 1958), Cystoseira humilis (Schousboe ex Kutzing, 1860), Cystoseira stricta (Sauvageau 1911), Fucus spiralis (Linnaeus 1753) and Gelidium sequipedale (Clemente) (Thuret 1876). Voucher specimens of all species were deposited in the National Herbarium (RAB) of the Moroccan Scientific Institute (Rabat, Morocco).

\subsection{Extract preparation.}

The collected algae samples were immediately brought to the laboratory in plastic bags containing natural seawater to prevent evaporation. Algae were thoroughly washed with fresh water to remove extraneous materials and air-dried at $60^{\circ} \mathrm{C}$. The dried algae were then ground in an electric mixer and stored at $4^{\circ} \mathrm{C}$ until use. The milled algae materials ( $25 \mathrm{~g}$ of each) were extracted twice with $80 \%$ methanol at room temperature overnight after being at $60^{\circ} \mathrm{C}$ for $2 \mathrm{~h}$. The crude extract was obtained by concentrating the supernatant using a rotary evaporator (Buchner) and a vacuum oven set at $30^{\circ} \mathrm{C}$. The crude extract was dissolved in water and then partitioned sequentially in four different solvents, n-Hexane (Hex), $\mathrm{CHCl}_{3}, \mathrm{EtOAc}$, and nbutanol $(\mathrm{BuOH})$ to fractionate the polar and non-polar compounds in the crude methanolic extract. The resulting solvent fractions were concentrated by a rotary evaporator and dried by a vacuum oven set at $30^{\circ} \mathrm{C}$. The crude extract and its solvent fractions were stored in the dark at $-20^{\circ} \mathrm{C}$ before analysis.

\subsection{Bioactive constituent.}

\subsubsection{Determination of total phenol content.}

Total polyphenol content (TCP) was determined according to the method of Slinkard and Singleton [34]. The calibration curve generated using the gallic acid standards was used to obtain the values for algae samples, which are expressed as micrograms of gallic acid equivalents (GAE) per milligram of crude extract or fraction $\left(\mu \mathrm{g} \mathrm{GAE} \mathrm{mg}^{-1}\right)$.

\subsubsection{Determination of total flavonoid content.}

The method reported in Tel et al. [35] was adopted for the determination of flavonoids. Flavonoid contents were calculated using a standard calibration curve prepared from quercetin. The concentrations of flavonoids in the test samples were calculated from the calibration plot and expressed as $\mu \mathrm{g}$ quercetin equivalent (QEs) per milligram of crude extract or fraction ( $\mu \mathrm{g}$ QEs $\left.\mathrm{mg}^{-1}\right)$.

\subsection{Antioxidant activity.}

\subsubsection{Ferric reducing power assay (FRAP).}

The reducing power of different extracts was determined using the method reported by Oyaizu [36] with slight modification. One milliliter of different concentrations of test samples $(0.2-1 \mathrm{mg} / \mathrm{mL})$ were mixed with $2.5 \mathrm{~mL}$ sodium phosphate buffer $(0.2 \mathrm{M}, \mathrm{pH} 6.6)$ and $2.5 \mathrm{~mL}$ of $1 \%$ potassium ferricyanide $\left(\mathrm{K}_{3} \mathrm{Fe}(\mathrm{CN})_{6}\right)$ solution. The mixture was incubated at $50^{\circ} \mathrm{C}$ for 20 $\min$. Then, trichloroacetic acid $(10 \%, 2.5 \mathrm{~mL})$ was added to the mixture. Next, $2.5 \mathrm{~mL}$ of this solution was mixed with $2.5 \mathrm{~mL}$ distilled water and $0.5 \mathrm{~mL}$ of $0.1 \% \mathrm{FeCl}_{3}$, and the absorbance was measured at $700 \mathrm{~nm}$. Blanc was prepared with all the reaction agents without extracts. 
Higher absorbance of the reaction mixture indicated that the reducing power was increased. Ascorbic acid was used as a positive control. The experiment was performed in triplicate.

\subsubsection{DPPH free radical scavenging assay.}

The free radical scavenging activity of extracts was determined by the DPPH assay described by Blois [37], with a slight modification. In its radical form, DPPH absorbs at 517 $\mathrm{nm}$, but its absorption decreases upon reduction by an antioxidant or radical species. Briefly, a $0.1 \mathrm{mM}$ solution of DPPH in methanol was prepared, and $160 \mu \mathrm{L}$ of this solution was added to $40 \mu \mathrm{L}$ of the sample solution in methanol at different concentrations $(0.2-1 \mathrm{mg} / \mathrm{mL})$. Thirty minutes later, the absorbance was measured at $517 \mathrm{~nm}$ using a 96-well microplate reader. Methanol was used as a control. Lower absorbance of the reaction mixture indicates higher free radical scavenging activity. The capability to scavenge the DPPH radical of an antioxidant was calculated using the following equation (1):

$$
\text { (1) DPPH scavenging effect }(\%)=\frac{\text { A control-A sample }}{\text { A control }} \times 100
$$

where $\mathrm{A}_{\text {control }}$ is the initial concentration of the DPPH, and Asample is the absorbance of the remaining concentration of DPPH in the presence of the sample. BHA and $\alpha$-tocopherol were used as antioxidant standards for comparison of the activity. IC50 values $(\mu \mathrm{g} / \mathrm{mL})$ were also determined for fractions or extracts that scavenged DPPH radicals at a rate superior to $50 \%$.

\subsubsection{ABTS cation radical decolorization assay.}

The spectrophotometric analysis of $\mathrm{ABTS}^{++}$scavenging activity was determined according to the method of [38] with slight modifications. The ABTS $^{+}$was produced by the reaction between $7 \mathrm{mM}$ ABTS in $\mathrm{H}_{2} \mathrm{O}$ and $2.45 \mathrm{mM}$ potassium persulfate, stored in the dark at room temperature for $12 \mathrm{~h}$. The radical cation was stable in this form for more than 2 days when stored in the dark at room temperature. Before usage, the $\mathrm{ABTS}^{++}$solution was diluted to achieve an absorbance of $0.708 \pm 0.025$ at $734 \mathrm{~nm}$ with ethanol. Then, $160 \mu \mathrm{L}$ of ABTS ${ }^{+}$ solution was added to $40 \mu \mathrm{L}$ of the sample solution in ethanol at different concentrations. After $10 \mathrm{~min}$, using a 96-well microplate reader, the percentage inhibition at $734 \mathrm{~nm}$ was calculated for each concentration relative to a blank absorbance. The scavenging capability of ABTS ${ }^{+}$ was calculated using the following equation (2):

(2) $\mathrm{ABTS}^{++}$scavenging effect $(\%)=\frac{\text { A control-A sample }}{\text { A control }} \times 100$

where $\mathrm{A}_{\text {control }}$ is the initial concentration of the $\mathrm{ABTS}^{+}$and $\mathrm{A}_{\text {sample }}$ is the absorbance of the remaining concentration of $\mathrm{ABTS}^{++}$in the presence of the sample. BHA and $\alpha$-tocopherol were used as antioxidant standards for comparison of the activity. IC50 values $(\mu \mathrm{g} / \mathrm{mL})$ were also determined for fractions or extracts that scavenged $\mathrm{ABTS}^{++}$radical over $50 \%$.

\subsection{Protective effect of selected extracts on hydrogen peroxide-induced cytotoxicity.}

\subsubsection{Cell culture of Tetrahymena pyriformis.}

A wild strain of Tetrahymena pyriformis was grown aerobically without shaking in a broth medium containing $1.5 \%$ protease-peptone, $0.25 \%$ yeast extract, and $0.2 \%$ glucose at $28^{\circ} \mathrm{C}$ during $72 \mathrm{~h} \mathrm{[39].} \mathrm{For} \mathrm{all} \mathrm{experiments,} \mathrm{the} \mathrm{protozoa} \mathrm{were} \mathrm{always} \mathrm{in} \mathrm{the} \mathrm{exponential} \mathrm{growth}$ phase, at a density of $1 \times 10^{4} / \mathrm{mL}$. 
To determine the effect of the selected algae extracts and hydrogen peroxide on the viability of $T$. pyriformis, the protozoa cells were grown in PPYG medium added with various concentrations of $\mathrm{H}_{2} \mathrm{O}_{2}(200-500 \mu \mathrm{g} / \mathrm{mL})$ to determine the sub-lethal concentration of $\mathrm{H}_{2} \mathrm{O}_{2}$. For selecting the extract which has the best activity, the cells were maintained in a PPYG medium supplemented with various concentrations of either ethyl acetate or chloroform fractions of F. Spiralis $(0.03-0.60 \mathrm{mg} / \mathrm{mL})$ to determine the non-toxic concentration extracts. To evaluate the protective effect of selected extracts on hydrogen peroxide-induced cytotoxicity, the culture of T. Pyriformis cells was treated with a non-toxic concentration of either the chloroform or ethyl acetate fraction from $F$. spiralis algae.

\subsubsection{Cell proliferation and viability assays.}

The effects of treatments with $\mathrm{H}_{2} \mathrm{O}_{2}$ with or without ethyl acetate or chloroform fraction aliquots on the proliferation of $T$. pyriformis were evaluated optically using a microscope. $T$. pyriformis cell viability and/or mitochondrial activity was determined using MTT (3-(4,5dimethylthiazol-2-yl)-2,5-diphenyltetrazolium bromide) assay method [40]. The MTT assay was performed in 96-well microplates. The formazan production due to dehydrogenase activity at $550 \mathrm{~nm}$ was measured at $540 \mathrm{~nm}$ with a microplate reader. The results were expressed as percentage viability and cell numbers compared to the control.

\subsection{Determination of antioxidant enzyme activities in T. pyriformis.}

\subsubsection{Preparation of crude extracts.}

Protozoan cells were harvested during the logarithmic growth phase by centrifugation at $12000 \mathrm{~g}$ for $15 \mathrm{~min}$. The pellet obtained was suspended in $1 \mathrm{~mL}$ of $50 \mathrm{mM}$ phosphate buffer at $\mathrm{pH}$ 7.4. The cells were then crushed in the cold $\left(-4 \mathrm{C}^{\circ}\right)$ with ultraturax for $20 \mathrm{~min}$, followed by sonication of the sample $(80 \mathrm{~W}, 60 \mathrm{~s})$. The obtained supernatant (soluble protein fraction) was considered as the crude cell-free extract used in all enzyme assays.

\subsubsection{CAT activity.}

CAT activity in the crude cell-free extract was measured according to the method as

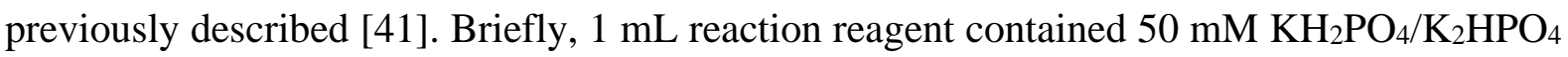
buffer, $30 \mathrm{mM} \mathrm{H}_{2} \mathrm{O}_{2}$, and was prepared at a $\mathrm{pH}$ of 7. CAT activity was calculated from the time of consumption of $\mathrm{H}_{2} \mathrm{O}_{2}$, resulting in an absorbance decrease at $240 \mathrm{~nm}$. The enzyme activity was expressed as mmol of $\mathrm{H}_{2} \mathrm{O}_{2}$ consumed $/ \mathrm{min} / \mathrm{mg}$ protein.

\subsubsection{SOD activity.}

The activity of SOD was determined according to the procedure of Paoletti et al. [42]. The total ( $\mathrm{Cu}-\mathrm{Zn}$ and $\mathrm{Mn})$ SOD activity was determined by measuring its ability to inhibit the photoreduction of nitroblue tetrazolium (NBT) [43]. One unit of SOD represents the amount inhibiting the photoreduction of NBT by $50 \%$. The activity was expressed as units/mg protein at $25^{\circ} \mathrm{C}$.

\subsubsection{GPx activity.}

GPx activity was measured following the method as previously described [44]. The reaction reagent consisted of $0.1 \mathrm{M}$ potassium phosphate buffer ( $\mathrm{pH}$ 7.4), $2 \mathrm{mM} \mathrm{GSH}, 10 \mathrm{mM}$ 
sodium azide, $0.5 \mathrm{mM}$ EDTA, $1 \mathrm{mM} \mathrm{H} \mathrm{H}_{2}$ and $0.3 \mathrm{~mL}$ of the extract. After incubation at $37^{\circ} \mathrm{C}$ for $15 \mathrm{~min}$, the reaction was terminated by the addition of trichloroacetic acid (TCA, 5\%, 0.5 $\mathrm{mL}$ ). Tubes were centrifuged at $1200 \mathrm{~g}$ for $5 \mathrm{~min}$, and the supernatant was collected. A quantity of $0.2 \mathrm{~mL}$ of phosphate buffer $(0.1 \mathrm{M} \mathrm{pH} 7.4)$ and $0.7 \mathrm{~mL}$ of DTNB $(0.4 \mathrm{mg} / \mathrm{mL})$ were added to $0.1 \mathrm{~mL}$ of reaction supernatant. After mixing, absorbance was recorded at $420 \mathrm{~nm}$. The activity was expressed as $\mu \mathrm{mol}$ of $\mathrm{GSH} / \mathrm{min} / \mathrm{mg}$ of soluble cell proteins at $25^{\circ} \mathrm{C}$.

2.6.5. Determination of reduced glutathione (GSH).

GSH levels were determined in the algal extracts using Ellman's method [45], with slight modifications. Briefly, the trichloroacetic acid solution was mixed with the extract. After centrifugation for $10 \mathrm{~min}$ at $12000 \mathrm{~g}$, the supernatant was collected and mixed with a phosphate buffer (50 Mm, pH 8) and $6 \mathrm{mM}$ 5,5-dithiobis (2-nitrobenzoic acid (DTNB)). The absorbance was read at $412 \mathrm{~nm}$. Reduced thiol contents were expressed in nmol of GSH/mg of protein.

\subsubsection{MDA content.}

MDA levels in the cell culture supernatant were determined spectrophotometrically, according to the method described by Ohkawa et al. [46]. $0.5 \mathrm{~mL}$ of supernatant was homogenized with trichloroacetic acid (TCA 20\%) and $1 \mathrm{~mL}$ thiobarbituric acid (TBA, 0.67\%). The mixture was heated at $100^{\circ} \mathrm{C}$ for $15 \mathrm{~min}$. After cooling, $4 \mathrm{~mL}$ of butanol was added to each sample and centrifuged at $3000 \mathrm{~g}$ for $15 \mathrm{~min}$. The intensity of the pink/red color of the supernatant was determined at $532 \mathrm{~nm}$. MDA levels were defined as nmol per $\mathrm{mg}$ of proteins.

\subsubsection{Protein assay.}

Protein content was measured by using bovine serum albumin (BSA) as the analytical standard, according to Lowry's methods [47].

\subsection{Calculation and analysis of data.}

Statistical analysis was performed using the SPSS 23. All data for both antioxidant and antioxidant enzyme activity tests were the average of triplicate analyses. Data were recorded as the mean \pm Standard Deviation (SD). Differences between means were determined using the Student's test. $p$ values $<0.05$ were taken as significant.

\section{Results and Discussion}

\subsection{Total bioactive compounds.}

In this study, the total phenolic content was expressed as $\mu \mathrm{g}$ GAE per gram of the extract and fraction. It can be seen from Table 1 that the brown algae $F$. spiralis and $C$. humulis contained higher amounts of polyphenols than the other algae, B. Bifurcata, G. sesquipedale, and $C$. humilis. This result is in accordance with the results reported previously [13-17]. The highest phenolic contents for EtOAc and $\mathrm{CHCl}_{3}$ fractions were found in $\mathrm{F}$. spiralis with values of $(429.81 \pm 9.36 ; 65.76 \pm 0.90 \mu \mathrm{g} \mathrm{GAE} / \mathrm{mg}$ extract $)$ and $C$. stricta $(381.33 \pm 10.81 ; 48.23 \pm 2.31$ $\mu \mathrm{g}$ GAE/mg extract), respectively. The lowest total phenolic contents were observed in $\mathrm{n}$ butanol and an aqueous fraction of C. Stricta, G. sesquipedale, C. humilis and B. bifurcata ranging from $5.19 \pm 0.27$ to $18.01 \pm 2.16 \mu \mathrm{g}$ GAE/mg extract, while $F$. spiralis showed higher 
amounts of phenolic contents in n-butanol $(45.24 \pm 0.59 \mu \mathrm{g} \mathrm{GAE} / \mathrm{mg}$ extract) compared to other species.

Table 1. Total bioactive contents of the methanol extracts and their fractions for the five algae species included in the study.

\begin{tabular}{l|l|l|l|l|l|l} 
& Crude extract & n-Hexan & Chloroform & Ethyl acetate & n-butanol & Aqueous \\
\hline \multicolumn{7}{c}{ Total phenolic contents $^{\mathbf{a}}$} \\
\hline B. bifurcata & $6.67 \pm 0.98$ & $9.35 \pm 1.10$ & $41.71 \pm 1.49$ & $16.71 \pm 0.75$ & $10.04 \pm 2.01$ & $11.91 \pm 1.94$ \\
\hline C. stricta & $43.33 \pm 8.23$ & $25.02 \pm 2.86$ & $48.23 \pm 2.31$ & $381.33 \pm 10.81$ & $18.01 \pm 2.16$ & $5.19 \pm 0.27$ \\
\hline C. humulis & $5.45 \pm 0.19$ & $11.17 \pm 1.67$ & $35.93 \pm 2.63$ & $11.13 \pm 2.46$ & $5.58 \pm 0.71$ & $8.23 \pm 0.52$ \\
\hline F. spiralis & $60.69 \pm 8.23$ & $61.95 \pm 2.78$ & $65.76 \pm 0.90$ & $429.81 \pm 9.36$ & $45.24 \pm 0.59$ & $21.43 \pm 3.32$ \\
\hline G. sesquipedale & $9.44 \pm 1.00$ & $12.99 \pm 7.11$ & $15.02 \pm 2.49$ & $61.52 \pm 6.88$ & $7.79 \pm 1.42$ & $13.12 \pm 1.92$ \\
\hline \multicolumn{7}{c}{ Total flavonoid contents ${ }^{\mathbf{b}}$} \\
\hline B. bifurcata & $13.47 \pm 0.63$ & $46.09 \pm 3.93$ & $73.98 \pm 2.67$ & $28.03 \pm 0.36$ & $7.87 \pm 0.47$ & $12.24 \pm 0.36$ \\
\hline C. stricta & $22.16 \pm 0.20$ & $127.32 \pm 0.45$ & $74.18 \pm 2.22$ & $34.7 \pm 0.24$ & $12.32 \pm 0.54$ & $10.49 \pm 0.72$ \\
\hline C. humulis & $12 \pm 0.47$ & $94.02 \pm 0.58$ & $35.37 \pm 0.66$ & $30.21 \pm 0.41$ & $14.74 \pm 1.03$ & $12.08 \pm 0.59$ \\
\hline F. spiralis & $25.02 \pm 0.54$ & $136.37 \pm 0.24$ & $111.92 \pm 3.93$ & $43.98 \pm 0.41$ & $7.4 \pm 0.24$ & $7 \pm 0.77$ \\
\hline G. sesquipedale & $20.61 \pm 0.59$ & $81.6 \pm 0.36$ & $60.53 \pm 1.15$ & $5.41 \pm 0.44$ & $7.79 \pm 0.59$ & $7.79 \pm 0.56$
\end{tabular}

Values expressed are means \pm SD of three parallel measurements $(p<0.05)$.

${ }^{\text {aT }}$ Total phenolic contents are expressed as $\mu \mathrm{g}$ GAE per mg of extract or fraction.

${ }^{\mathrm{b}}$ Total flavonoid contents are expressed as $\mu \mathrm{g}$ QE per mg extract or fraction

The red algae, G. sesquipedale showed a decrease of polyphenol contents in the EtOAc fraction (61.52 \pm 3.97$)$ when compared to its other solvent fractions. In other studies, the methanolic fraction from $F$. spiralis showed the highest total phenolic content compared to methanol and dichloromethane fractions from twenty-seven other macroalgae species [48]. Our findings are in agreement with those of previous studies, whereas brown algae species were found to contain predominantly polyphenolic compounds in the organic solvents such as EtOAc and dichloromethane [49]. Previous studies have reported that the dichloromethane fraction of $F$. spiralis and EtOAc fraction of B. bifurcata showed higher phenolic contents (29.79 and $24.44 \mathrm{mg} \mathrm{GAE/g} \mathrm{dry} \mathrm{weight} \mathrm{extract,} \mathrm{respectively)} \mathrm{when} \mathrm{compared} \mathrm{to} \mathrm{other} \mathrm{solvent}$ fractions and crude methanol extract. However, the relatively high phenolic contents of the EtOAc fraction are probably associated with its polarity which allows the accumulation of a variety of antioxidant compounds. Previous studies have reported that all the Fucus species tested had high total phenolic contents [17]. This might be due to their high content of phlorotannins, which are polymers of phloroglucinol derived entirely from acetate. Phlorotannins are restricted to brown algae (Phaeophyta), where they are found in special vesicles (physodes) within the cells [50].

Flavonoids are natural polyphenolic compounds and well-known antioxidants, playing significant roles in detoxification of free radicals. It has been recognized that flavonoids show antioxidant activity, and their effects on human nutrition and health are considerable. Their concentration in the extracts was expressed as micrograms of quercetin equivalents per milligram of extract and fraction ( $\mu \mathrm{g}$ QEs $/ \mathrm{mg}$ extract or fraction), as shown in Table 1. Among the algae extracts, F. Spiralis showed the highest flavonoid contents followed by C. stricta, $G$. sesquipedale, C. humilis, and B. bifurcata. All n-hexane and chloroform fractions of the studied algae species were found to be more effective than the other fractions. $F$. spiralis exhibited the highest flavonoid amount that was observed in n-hexane and chloroform fractions with values of (136.37 \pm 0.24 and $111.92 \pm 3.93 \mu \mathrm{g}$ QEs/mg extract, respectively).

As expected, aqueous residue and n-butanol fractions of all species were found to be generally poor in flavonoids, with the exception of the EtOAc fraction of G. sesquipedale (5.41 $\pm 0.44 \mu \mathrm{g}$ QEs/mg extract) which, on the study level, was the poorest in flavonoid contents. The high flavonoid content in the n-hexane fraction has been previously explained by the 
presence of carotenes or other pigments with long hydrocarbon chains [51]. Earlier studies have shown that a change in extractant polarity alters its efficiency to extract a specific group of antioxidant compounds and that influences the antioxidant properties of the extracts [52-53]. In other studies, extraction of algae using ethyl acetate and chloroform gave higher contents of phenols and flavonoids than water and methanol, suggesting a higher affinity to lipophilic rather than hydrophilic antioxidants [54].

\subsection{Antioxidant activities of algae extracts and fractions.}

In this study, the antioxidant activity of the various extracts obtained from the five algae species, compared to those of butylated hydroxytoluene (BHT) and $\alpha$-tocopherol, were assessed by four complementary tests, namely, ABTS, DPPH and the FRAP assay for free radical scavenging activity. As observed in Table 2, the algae species showed significant differences in the ferric reducing power of crude methanol extract and its solvent fraction.

Table 2. Antioxidant activities of the extracts and fractions of five algae species by FRAP, DPPH and ABTS ${ }^{+}$assays.

\begin{tabular}{|c|c|c|c|c|}
\hline & Algae species & FRAP ${ }^{a}$ & DPPH $^{b}$ & ABTS $^{c}$ \\
\hline \multirow[t]{5}{*}{ Methanol } & B. bifurrcata & $11.06 \pm 0.20$ & $861.82 \pm 0.77$ & $1174.99 \pm 8.55$ \\
\hline & C. stricta & $17.66 \pm 0.28$ & $666.34 \pm 0.74$ & $776.07 \pm 1.30$ \\
\hline & C. humulis & $11.4 \pm 0.5$ & $830.21 \pm 3.69$ & $1062.40 \pm 13.95$ \\
\hline & F. spiralis & $59.03 \pm 1.05$ & $355.29 \pm 0.12$ & $627.89 \pm 3.25$ \\
\hline & G. sesquipedale & $5.06 \pm 0.58$ & $1490.82 \pm 0.47$ & $783.45 \pm 22.67$ \\
\hline \multirow[t]{5}{*}{ Hexan } & B. bifurrcata & $22.73 \pm 0.51$ & $442.33 \pm 5.22$ & $1646.73 \pm 17.26$ \\
\hline & C. stricta & $68.8 \pm 0.34$ & $347.52 \pm 8.44$ & $1075.54 \pm 8.80$ \\
\hline & C. humulis & $1 \pm 0.36$ & $342.67 \pm 0.20$ & $1135.81 \pm 1.98$ \\
\hline & F. spiralis & $73.46 \pm 2.05$ & $175.34 \pm 1.01$ & $1125.39 \pm 34.84$ \\
\hline & G. sesquipedale & $6.76 \pm 0.61$ & $1326.38 \pm 1.93$ & $1134.66 \pm 1.98$ \\
\hline \multirow[t]{5}{*}{$\mathrm{CHCl}_{3}$} & B. bifurrcata & $12.63 \pm 0.45$ & \begin{tabular}{|l|l|}
$647.75 \pm 0.63$ \\
\end{tabular} & $1317.17 \pm 0.02$ \\
\hline & C. stricta & $10.36 \pm 0.20$ & $165.92 \pm 2.63$ & $537.94 \pm 3.60$ \\
\hline & C. humulis & $18.76 \pm 0.41$ & $217.88 \pm 1.08$ & $1101.65 \pm 27.60$ \\
\hline & F. spiralis & $117.66 \pm 0.40$ & $55.48 \pm 0.20$ & $219.82 \pm 5.47$ \\
\hline & G. sesquipedale & na & $1341.36 \pm 1.22$ & $560.58 \pm 24.43$ \\
\hline \multirow[t]{5}{*}{ AcET } & B. bifurrcata & $41.2 \pm 0.36$ & $447.20 \pm 3.60$ & $1025.48 \pm 1.82$ \\
\hline & C. stricta & $208.76 \pm 0.32$ & $85.47 \pm 2.22$ & $395.50 \pm 12.05$ \\
\hline & C. humulis & $32.16 \pm 0.51$ & $145.93 \pm 2.59$ & $831.44 \pm 7.27$ \\
\hline & F. spiralis & $261.53 \pm 5.40$ & $49.51 \pm 3.29$ & $50.73 \pm 2.62$ \\
\hline & G. sesquipedale & $4.33 \pm 0.76$ & $1043.61 \pm 0.68$ & $475.93 \pm 3.89$ \\
\hline \multirow[t]{5}{*}{$N$-But } & B. bifurrcata & $10.3 \pm 0.8$ & $1074.07 \pm 0.64$ & $1241.06 \pm 16.67$ \\
\hline & C. stricta & $0.43 \pm 0.20$ & $1155.79 \pm 1.33$ & $1181.28 \pm 7.34$ \\
\hline & C. humulis & $8.83 \pm 0.15$ & $716.06 \pm 0.57$ & $1748.00 \pm 5.08$ \\
\hline & F. spiralis & $34.4 \pm 0.91$ & $529.32 \pm 3.68$ & $977.94 \pm 1.75$ \\
\hline & G. sesquipedale & na & $1752.45 \pm 7.44$ & $1909.96 \pm 26.53$ \\
\hline \multirow[t]{6}{*}{ Aqueous } & B. bifurrcata & $8.33 \pm 0.64$ & $1165.78 \pm 9.32$ & $3242.12 \pm 0.31$ \\
\hline & C. stricta & na & $1526.87 \pm 0.54$ & $2420.68 \pm 32.51$ \\
\hline & C. humulis & na & $2368.11 \pm 0.22$ & $2730.50 \pm 0.88$ \\
\hline & F. spiralis & $26.46 \pm 0.96$ & $1427.59 \pm 0.34$ & $1621.94 \pm 0.89$ \\
\hline & G.sesquipedale & na & $2167.79 \pm 4.90$ & $2015.12 \pm 0.12$ \\
\hline & BHT & $\mathrm{nt}$ & $54.96 \pm 0.99$ & $4.10 \pm 0.06$ \\
\hline
\end{tabular}

$\mathrm{IC}_{50}$ values represent the means $\pm \mathrm{SD}$ of three parallel measurements $(p<0.05)$.

${ }^{a}$ FRAP ( $\mu \mathrm{g}$ ascorbic acid Equivalent/mg extract or fraction).

${ }^{b} \mathrm{DPPH}$ radical scavenging activity $\left(\mathrm{IC}_{50} \mathrm{mg} / \mathrm{mL}\right)$.

${ }^{\mathrm{c}} \mathrm{ABTS}\left(\mathrm{IC}_{50} \mathrm{mg} / \mathrm{mL}\right)$.

nt: not tested, na: no activity.

The FRAP values of the algae extracts and fractions ranged between $(0.43 \pm 0.002$ and $261.53 \pm 0.054 \mu \mathrm{g}$ AscAE/mg extract). The highest FRAP values were for Ethyl acetate, chloroform, and n-Hexan of $F$. spiralis with values of $261.53 \pm 0.05,117.66 \pm 0.004$ and 73.46 $\pm 0.020 \mu \mathrm{g} \mathrm{AscAE} / \mathrm{g}$ extract, respectively. However, the aqueous residue fractions possessed the lowest FRAP values relative to other fractions. The FRAP value of crude extracts and fractions from five algae species revealed decreasing FRAP values in the order of $F$. spiralis, C. stricta, B. bifurcata, C. Humilis, and G. sesquipedale. In agreement with our results, 
previous studies revealed that fucus species exhibited higher FRAP activities than other species [55-56]. In a study, the ferric reducing antioxidant activity of 30 species of Hawaiian algae, and the brown algae presented the highest mean antioxidant values among Hawaiian algae [14]. However, the red algae had the lowest FRAP value. From these results, the EtOAc and $\mathrm{CHCl}_{3}$ fractions of $F$. spiralis had the ability to reduce the $\mathrm{Fe}^{3+}$ to $\mathrm{Fe}^{2+}$, which indicates the possible role in human tissues and foods samples to inhibit lipoperoxidation initiated by transition metal ions such as $\mathrm{Fe}^{3+}$ and $\mathrm{Cu}^{2+}$. The Ferric reducing antioxidant activity was also evaluated by the FRAP system in the fraction of three brown macroalgae (Ascophyllum nodosum, Pelvetia canaliculata and Fucus spiralis) from Irish coast and they obtained a significant increase in activity in the fraction of $F$. spiralis with values of $559.96 \pm 26.69 \mu \mathrm{g}$ Trolox equivalents (TE) $\mathrm{mg} / \mathrm{mg}$ sample [57]. Marine algae are exposed to prolonged intense ultraviolet and high oxygen concentration that readily lead to the formation of free radicals and other reactive oxygen species [58-59). The long-term exposure to the harsh environment conditions implies that algae have protective enzymes and potent antioxidant molecules that can behave as reactive oxygen scavengers [17-58].

The DPPH free radical-scavenging model is widely accepted as a tool for investigating the free radical scavenging activities of antioxidants. In this study, the free radical scavenging ability of methanolic and solvent fractions of five algae was evaluated through the change of absorbance caused by the reduction of DPPH radical. As can be seen in Table 2, the antioxidant activity assessed with DPPH depends on the solvent extraction and the algae species. As shown in Table 2, the DPPH radical scavenging activities of the five algae crude extracts and their solvent fractions varied considerably from $49.51 \pm 3.29$ to $2167.79 \pm 4.90 \mu \mathrm{g} / \mathrm{mL}$ of fraction or extracts $(p<0.05)$. In general, the highest DPPH radical-scavenging activities were reordered in the EtOAc and $\mathrm{CHCl}_{3}$ fraction of the brown algae $F$. spiralis $(49.51 \pm 3.29$ and $55.48 \pm 0.20$ $\mu \mathrm{g} / \mathrm{mL}$, respectively) followed by the EtOAc and $\mathrm{CHCl}_{3}$ fractions of $C$. stricta $(85.47 \pm 2.22$ and $165.92 \pm 2.63 \mu \mathrm{g} / \mathrm{mL}$, respectively). The lowest values of DPPH radical scavenging activity were observed in methanolic crude extract and its solvent fractions of G. sesquipedale with values ranging from $1043.61 \pm 0.68$ to $2167.79 \pm 4.90 \mu \mathrm{g} / \mathrm{mL}$. Earlier reports indicate that the polar solvent fractions (ethyl acetate and dichloromethane) of algae contain the highest percentages of total phenolic contents and exhibit a higher antioxidant potential based on the DPPH radical assay [18]. It has also been shown that the solvents used for extraction dramatically influence the chemical composition of the extracts [60]. Andrade et al. evaluated the antioxidant capacity of several algae, and they found that brown algae possess the most potent radical scavenging activity [61].

The higher DPPH radical scavenging is thought to be due to an increase of total phenolic content in these fractions. Thus they act as electron donors because of their hydrogendonating ability and neutralization of free radicals. Previous studies have demonstrated a positive correlation between total phenolic contents and antioxidant activities in deferment algae extracts, particularly in terms of DPPH radical scavenging activity [18-48].

As shown in Table 2, the ABTS radical scavenging activity of crude methanolic extracts from the five species can be ranked in the following order of decreasing radical scavenging activity: F. spiralis, C. stricta, G. sesquipedale, C. Humilis, B. bifurcata. The IC50 value for ABTS radical-scavenging activity differed among the algae species and solvents used. The ABTS radical scavenging activities of Moroccan algae varied considerably from $50.73 \pm 2.62$ to $3242.12 \pm 0.31 \mu \mathrm{g} / \mathrm{mL}$ of crude extract or fraction. For the methanolic crude extract, antioxidant activity ranged from $627.89 \pm 3.25$ to $1174.99 \pm 8.55 \mu \mathrm{g} / \mathrm{mL}$, which is lower than the 
purified fraction. $F$. spiralis was found to have the highest antioxidant activity $(627.89 \pm 3.25$ $\mu \mathrm{g} / \mathrm{mL})$, followed by $C$. stricta $(776.07 \pm 1.30 \mu \mathrm{g} / \mathrm{mL})$ and $G$. sesquipedale $(783.45 \pm 22.67 \mu \mathrm{g} / \mathrm{mL})$. Among all species tested, ethyl acetate and chloroform fractions of $F$. spiralis showed the most scavenging activity on ABTS radicals $(50.73 \pm 2.62$ and $219.82 \pm 5.47$ $\mu \mathrm{g} / \mathrm{mL}$, respectively), followed by the ethyl acetate and chloroform fractions of C. stricta (395.50 \pm 12.05 and $537.94 \pm 3.60 \mu \mathrm{g} / \mathrm{mL}$, respectively). However, methanolic crude extract and its fraction from $B$. bifurcata showed less scavenging activity than from other species. The aqueous, n-butanol, and n-hexane fractions of all algae species showed the lowest IC $_{50}$ value of ABTS radical scavenging activity than other algal fractions. In general, the highest antioxidant activities were found in the purified fraction than in methanolic crude extract. In another study, the ABTS radical scavenging activity of different extracts from Ascophyllum nodosum was measured, and the crude extracts were less effective antioxidants than purified ones [62]. Many researchers have shown that polyphenolic compounds extracted from marine algae exhibited high potent antioxidants activity against free radical cation activity [18]. In accordance with total phenolic content and DPPH radical scavenging activity, the ABTS results were again found in the methanolic and fraction of brown algae $F$. spiralis.

Due to the high total phenolic contents and the high antioxidant capacities of the EtOAc and $\mathrm{CHCl}_{3}$ fractions of the brown algae $F$. spiralis, the protective effect of these fractions against peroxide hydrogen induced-cytotoxicity in the $T$. pyriformis protozoan was investigated further.

\subsection{Cytotoxicity of $\mathrm{H}_{2} \mathrm{O}_{2}$ on T. pyriformis.}

The protozoan T. pyriformis, a eukaryotic cell, is well-established as a suitable model for higher animal cells, especially mammalian. The unicellular ciliate $T$. pyriformis, is an appropriate system for a number of studies, including cell morphogenesis, gene mapping, cell division, and in toxicant screening studies in environmental and pharmaceutical fields [63].


Figure 1. T. pyriformis was cultivated in PPYG medium in the presence of different concentrations of $\mathrm{H}_{2} \mathrm{O}_{2}(100$ $300 \mu \mathrm{M}$ ). (a) Results were obtained by the MTT method. (b) Effect of $\mathrm{H}_{2} \mathrm{O}_{2}$ on T. pyriformis growth. The results shown are the mean \pm SD of the three independent experiments. Values were normalized to the control and are given as percent of the control. The significance following the Student t-test are shown as: $p<0.05$ for *; $p<0.01$ for $* * ; p<0.001$ for $* * *$. 
The protozoan $T$. pyriformis was grown with different concentrations of $\mathrm{H}_{2} \mathrm{O}_{2}$, as mentioned in materials and methods. We chose to promote stress using $\mathrm{H}_{2} \mathrm{O}_{2}$ because it is relatively stable and thus enables us to impose reproducible oxidative stress upon the cells. The cytotoxicity induced using different concentrations over the range of 100 to $500 \mu \mathrm{M}$ was assessed in T. pyriformis using the enumeration cells and MTT assays. The results show that the treatment with $\mathrm{H}_{2} \mathrm{O}_{2}$ resulted in a significant decrease in cell viability (Figure 1a) $(p<0.05$ ), and the number of cells was remarkably reduced (Figure1b). Moreover, the treatment with 300 $\mu \mathrm{M}$ of $\mathrm{H}_{2} \mathrm{O}_{2}$ produced a significant decrease in the cell viability with $52 \%(p<0.01)$ and the number of cells with $48 \%$ after 24 hours of treatment. The concentrations under $300 \mu \mathrm{M}$ are toxic and lethal (Figure 1a). These results were in agreement with the finding of previous studies that reported that $300 \mu \mathrm{M}$ of $\mathrm{H}_{2} \mathrm{O}_{2}$ inhibited the growth of $T$. pyriformis by half [6465]. Results from other studies have shown that hydrogen peroxide induces oxidative stress and cell death in murine hippocampal HT22 cells [24] and that hydrogen peroxide can inhibit the growth, shape, density, and mobility of T. pyriformis [66].

\subsection{Effect of the algae extracts on the growth of T. pyriformis.}

To determine the non-lethal concentration of each fraction extract (EtOAc and $\mathrm{CHCl}_{3}$ ) of $F$. spiralis on $T$. pyriformis, cell viability and cell numbers were determined. As shown in Figure 2, $\mathrm{CHCl}_{3}$ (a) and EtOAc (b) fractions were not cytotoxic up to the concentration of 0.09 and $0.12 \mu \mathrm{g} / \mathrm{mL}$ of EtOAc and $\mathrm{CHCl}_{3}$, respectively. In a similar study, the cytotoxicity of five fractions obtained from $F$. spiralis was tested on MCF-7 cells, and it was also shown that none of the fractions $(1 \mathrm{mg} / \mathrm{mL})$ presented cytotoxicity [30].
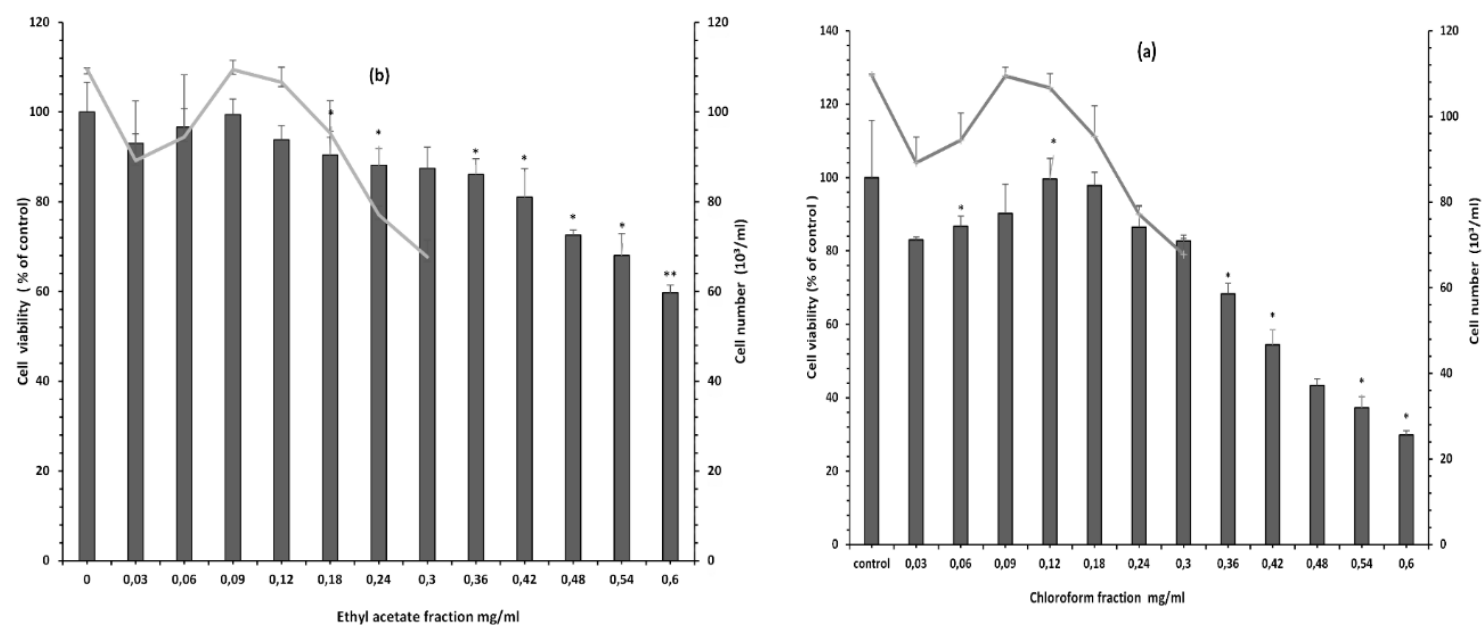

Figure 2. Effect of algae on the growth of Tetrahymena pyriformis. The cells were maintained in PPYG medium supplemented with different concentrations of (a) chloroform or $(\mathbf{b})$ ethyl acetate $(0.03-0.6 \mathrm{mg} / \mathrm{ml})$.

Values of MTT were normalized to the control and are given as percent of the control. The significance following the Student t-test are shown as: $p<0.05$ for *; $p<0.01$ for **; $p<0.001$ for ***.

\subsection{Protective effect against $\mathrm{H}_{2} \mathrm{O}_{2}$-induced cytotoxicity on T. pyriformis.}

Cell viability was measured with the MTT test, allowing quantifying the enzymatic activity of dehydrogenase, which takes into account mitochondrial dysfunctions and/or cell growth inhibition. As shown in Figure 3, When $\mathrm{H}_{2} \mathrm{O}_{2}$ was applied at $300 \mu \mathrm{M}$ for $24 \mathrm{~h}$, a significant decrease of the cell viability $(51.89 \%)$ was observed as compared to the control. 
On the other hand, in the cells treated with of EtOAc $(0.09 \mu \mathrm{g} / \mathrm{mL})$ and $\mathrm{CHCl}_{3}(0.12 \mu \mathrm{g} / \mathrm{mL})$ and exposed to $\mathrm{H}_{2} \mathrm{O}_{2}(300 \mu \mathrm{M})$, we noted that the pre-treatment significantly restored the cell viability to $82.02 \%$ and $83 \%$ of control for EtOAc $(0.09 \mu \mathrm{g} / \mathrm{mL})$ and $\mathrm{CHCl}_{3}(0.12 \mu \mathrm{g} / \mathrm{mL})$, respectively. These results indicate that both fractions had a strong scavenging effect on hydrogen peroxide. They inhibited $\mathrm{H}_{2} \mathrm{O}_{2}$-induced cytotoxicity of $T$. pyriformis and showed a significant protective effect against oxidative stress by $\mathrm{H}_{2} \mathrm{O}_{2}$. In previous studies, the methanolic fraction of Padina pavonica and Fucus spiralis presented the highest activities $(81.12 \pm 2.92$ and $80.5 \pm 2.25 \%$ of viable cells, respectively), at $0.5 \mathrm{mg} / \mathrm{mL}$ concentration when MCF-7 cells were exposed to $0.2 \mathrm{mM}$ of $\mathrm{H}_{2} \mathrm{O}_{2}$ [48]. In other studies, the pre-treatment with the extract up to the concentration of $62.5 \mathrm{mg} / \mathrm{mL}$ from $C$. tamariscifolia against oxidative stress imposed by $100 \mu \mathrm{M} \mathrm{H}_{2} \mathrm{O}_{2}$ treatment on $\mathrm{SH}-\mathrm{SY} 5 \mathrm{Y}$, enhanced cell survival up to almost $100 \%$ compared with the $\mathrm{H}_{2} \mathrm{O}_{2}$-treated group, which had a viability of 53.4\% [25]. Herein, when adding EtOAc and $\mathrm{CHCl}_{3}(90$ and $120 \mu \mathrm{g} / \mathrm{mL}$ ), F. spiralis fraction prevented the reduction of cell viability induced by $\mathrm{H}_{2} \mathrm{O}_{2}$.

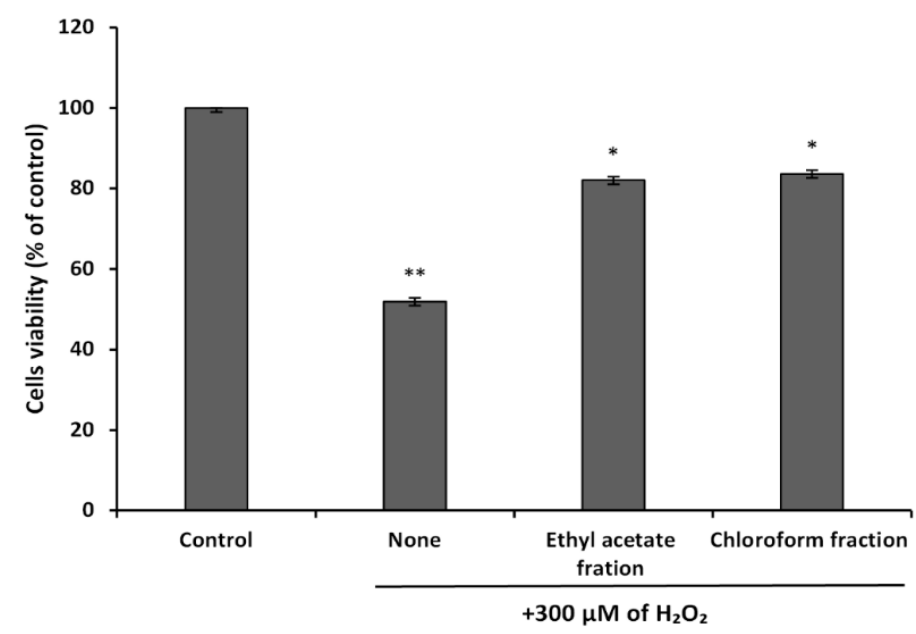

Figure 3. The protective effect of ethyl acetate $(0.09 \mu \mathrm{g} / \mathrm{ml})$ and chloroform fraction $(0.12 \mu \mathrm{g} / \mathrm{ml})$ on hydrogen peroxide promoted oxidative stress conditions in T. pyriformis promoted by $\mathrm{H}_{2} \mathrm{O}_{2}$ at $300 \mu \mathrm{M}$ after 24 hours of incubation. Cell viability was determined via the MTT method. The values in each column represent the mean \pm SD. ${ }^{*} p<0.001$, represent statistically significant differences compared with the control. \#p $<0.001$ represents statistically significant differences compared to the $\mathrm{H}_{2} \mathrm{O}_{2}$ condition.

\subsection{Effect of extract on antioxidant enzyme activities.}

The results of the protective effect of algae as having possible antioxidant effects are shown in (Figure 4). According to our results, in T. pyrifomis cells treated by $300 \mu \mathrm{M} \mathrm{H}_{2} \mathrm{O}_{2}$, the enzymatic activities of SOD, GPx, CAT (Figure 4a, 4b, 4c), MDA and GSH levels (Figure $4 \mathrm{~d}, 4 \mathrm{e}$ ) were increased when compared to controls. However, when T. pyrifomis was grown in the medium supplemented with EtOAc or $\mathrm{CHCl}_{3}$ fraction and exposed to $\mathrm{H}_{2} \mathrm{O}_{2}$, it significantly decreased the antioxidant enzymes (SOD, GPx, and CAT) and levels of (MDA and GSH) to near normal values, when compared to $\mathrm{H}_{2} \mathrm{O}_{2}$ treated $T$. pyriformis. The treatment with EtOAc and $\mathrm{CHCl}_{3}$ preserves the normal levels of antioxidant enzymes, MDA, and GSH levels. This effect may be due to the antioxidant effect of phenolic compounds, which may blunt oxidative injuries through scavenging reactive species and inhibiting lipid peroxidation [22]. The antioxidant protective effects of algae are related to biologically active substances, including polyphenols and phlorotannins [24]. In the brown algae, phlorotannins are known to constitute up to $15 \%$ of the dry weight of brown algae [67]. 

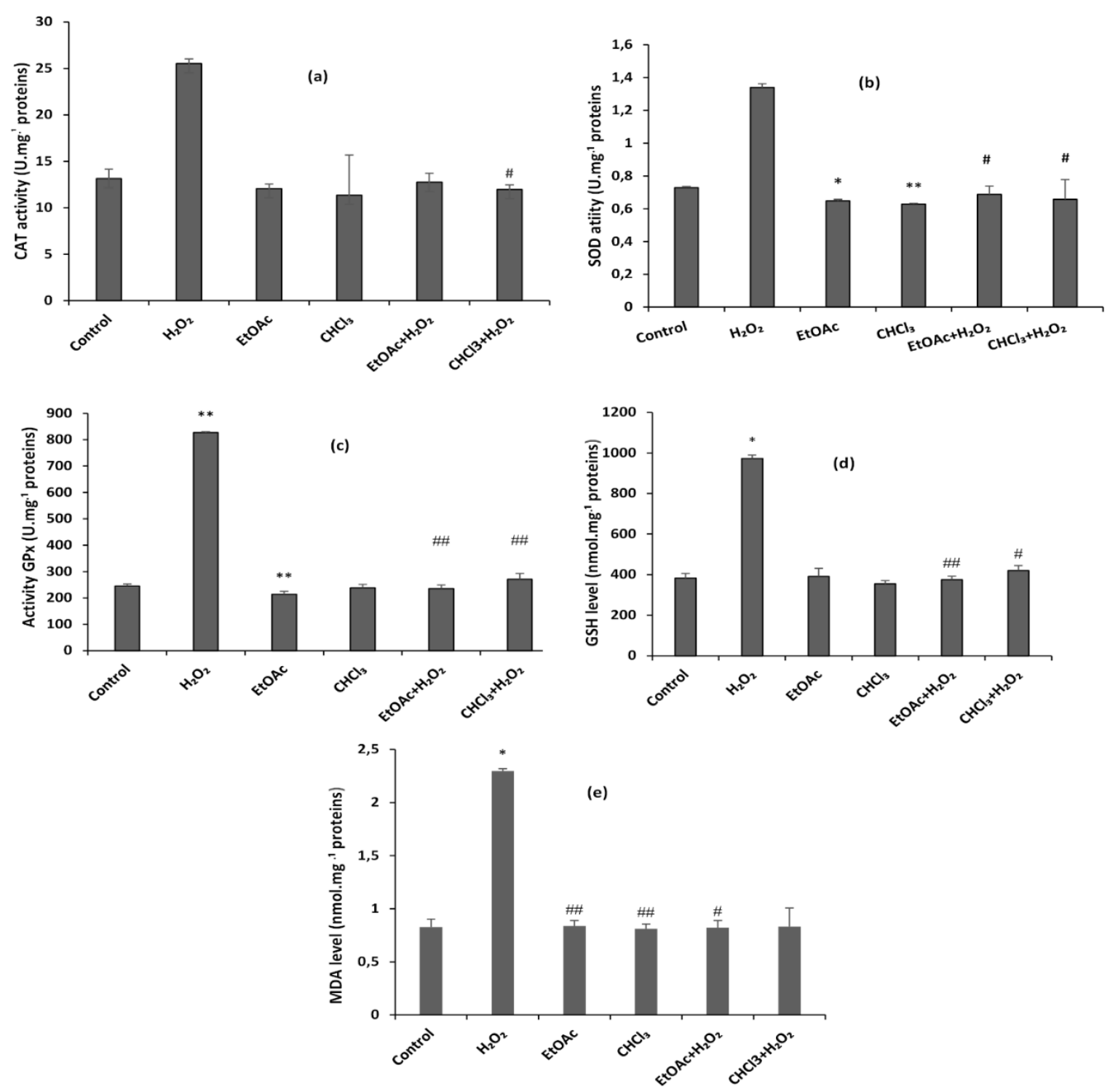

Figure 4. (a) CAT, (b) SOD, (c) GPx, (d) GSH and (e) MDA. The values in each column represent the mean \pm SD. ${ }^{*} p<0.001$, represent statistically significant differences compared with the control. \#p<0.001, represent statistically significant differences compared with $\mathrm{H}_{2} \mathrm{O}_{2}$ condition.

CAT is considered the most important enzyme for the break-down of $\mathrm{H}_{2} \mathrm{O}_{2}$ to water, oxygen, and other non-toxic products [68]. SOD protects a cell by catalyzing the conversion of superoxide radicals to $\mathrm{H}_{2} \mathrm{O}_{2}$, which is decomposed by GPx [69]. GPx removes $\mathrm{H}_{2} \mathrm{O}_{2}$ by the oxidation of GSH, but it converts lipid peroxides to harmless molecules protecting the cells from the consequences of lipid peroxidation. Previous reports related to the effect of $\mathrm{H}_{2} \mathrm{O}_{2}$ on redox status revealed that this oxidant displayed an increase in CAT and SOD in the protozoan Tetrahymna thermophile [64]. $\mathrm{H}_{2} \mathrm{O}_{2}$ induced oxidative stress was previously demonstrated in many cell types $[24,70]$. In the murine hippocampal HT22 cells, peroxide hydrogen significantly increased levels of intracellular $\mathrm{Ca}^{2+}$ concentration, which induced cell death. Therefore, phlorotannins isolated from the brown algae Ecklonia cava inhibit $\mathrm{H}_{2} \mathrm{O}_{2}$ induced oxidative stress and cell death by inhibiting $\mathrm{Ca}^{2+}$ increase [24]. Similarly, another study has reported that $\mathrm{H}_{2} \mathrm{O}_{2}$ enhances mitochondrial transmembrane potential and caspase- 9 activity in the MCF- 7 cells, whereas the treatment with algae extracts of Ulva Compresa, Cystoseira tamariscifolia, Sargassum muticum, Fucus spiralis, and Padina pavonica increases the cell viability through inhibition of the caspase- 9 activity and reduced mitochondrial membrane depolarization [48]. It has been shown that $\mathrm{H}_{2} \mathrm{O}_{2}$ acts as a biological oxidant, and contributes 
to the increase of cytosolic $\mathrm{Ca}^{2+}$ and oxidative stress, which is involved in cell death mechanisms [70-71]. It has been reported that apoptosis death is related to the decrease in the mitochondrial membrane potential, which is associated with the release of cytochrome $\mathrm{c}$ and sequential activation of caspases [72]. In the apoptotic process, an increase of cytosolic $\mathrm{Ca}^{2+}$ and oxidative stress contribute to the opening of the mitochondrial permeability transition pore (PTP), which depolarizes the mitochondria and leads to mitochondrial swelling and subsequent release of cytochrome c into the cytosol [73-74].

Our data show that the ethyl acetate and chloroform fractions from $F$. spiralis extract are able to counteract $\mathrm{H}_{2} \mathrm{O}_{2}$-induced cell growth inhibition. Algae is a possible source of useful antioxidative compounds, and different compounds can be obtained as a result of the selection of the extraction solvent.

\section{Conclusions}

In summary, this study showed that extraction solvents had a significant impact on the phenolic, flavonoid contents and are against various oxidative systems under in vitro condition. Overall, EtOAc and $\mathrm{CHCl}_{3}$ of $F$. spiralis contained the highest antioxidant activities. The present study demonstrated that the EtOAc and $\mathrm{CHCl}_{3}$ fraction from $F$. spiralis algae could significantly reduce oxidative stress in T. Pyriformis against $\mathrm{H}_{2} \mathrm{O}_{2}$ induced cytotoxicity. These results indicate that $F$. spiralis has therapeutic effects for some health problems associated with oxidative stress, and this was established by its protective effect on redox status and cell viability. Significant efforts should be made to identify and isolate the bioactive compounds that are involved in the antioxidant activities of these algae species.

\section{Funding}

This research received no external funding.

\section{Acknowledgments}

We thank Dr. Abedlouahid Chriyaa for his contribution to the manuscript reading.

\section{Conflicts of Interest}

The authors declare no conflict of interest.

\section{References}

1. Circu, M.L.; Aw, T.Y. Reactive Oxygen Species, Cellular Redox Systems, and Apoptosis. Free Radic. Biol. Med. 2010, 48, 749-762, https://doi.org/10.1016/j.freeradbiomed.2009.12.022.

2. Yoshikawa, T.; Naito, Y. What Is Oxidative Stress ? J. Japan Med. Assoc. 2002, 45, 271-276.

3. Carocho, M.; Ferreira, I.C.F.R. A Review on Antioxidants, Prooxidants and Related Controversy: Natural and Synthetic Compounds, Screening and Analysis Methodologies and Future Perspectives. Food Chem. Toxicol. 2013, 51, 15-25, https://doi.org/10.1016/j.fct.2012.09.021.

4. Rhee, S.G.; Chang, T.; Jeong, W.; Kang, D. Methods for Detection and Measurement of Hydrogen Peroxide inside and Outside of Cells. Mol. Cells 2010, 29, 539-549, https://doi.org/10.1007/s10059-0100082-3.

5. Barbosa, M.P.R.; Mendes, L.D.S.; Vilela, D.d.A.; Veras, M.; Rocha, J.C.T. Can Oxidative Stress Markers Help Define Stroke Prognosis? Biointerface Res. Appl. Chem. 2019, 10, 4864-4868, https://doi.org/10.33263/BRIAC101.864868.

6. Murray, P.M.; Moane, S.; Collins, C.; Beletskaya, T.; Thomas, O.P.; Duarte, A.W.F.; Nobre, F.S.; Owoyemi, I.O.; Pagnocca, F.C.; Sette, L.D.; McHugh, E.; Causse, E.; Pérez-López, P.; Feijoo, G.; Moreira, M.T.; Rubiolo, J.; Leirós, M.; Botana, L.M.; Pinteus, S.; Alves, C.; Horta, A.; Pedrosa, R.; 
Jeffryes, C.; Agathos, S.N.; Allewaert, C.; Verween, A.; Vyverman, W.; Laptev, I.; Sineoky, S.; Bisio, A.; Manconi, R.; Ledda, F.; Marchi, M.; Pronzato, R.; Walsh, D.J. Sustainable Production of Biologically Active Molecules of Marine Based Origin. N. Biotechnol. 2013, 30, 839-850, https://doi.org/10.1016/j.nbt.2013.03.006.

7. Kazakov, Y.; Tarasov, A.; Alyoshina, L.; Brainina, K. Interplay between Antioxidant Activity, Health and Disease. Biointerface Res. Appl. Chem. 2019, 10, 4893-4901, https://doi.org/10.33263/BRIAC101.893901.

8. Qin, Y. Applications of Bioactive Seaweed Substances in Functional Food Products. J. Food Sci. Technol. 2019.

9. Gomez-Zavaglia, A.; Prieto Lage, M.A.; Jimenez-Lopez, C.; Mejuto, J.C.; Simal-Gandara, J. The Potential of Seaweeds as a Source of Functional Ingredients of Prebiotic and Antioxidant Value. Antioxidants. 2019, 8, https://doi.org/10.3390/antiox8090406.

10. Hannan, M.A.; Sohag, A.A.M.; Dash, R.; Haque, M.N.; Mohibbullah, M.; Oktaviani, D.F.; Hossain, M.T.; Choi, H.J.; Moon, I.S. Phytosterols of Marine Algae: Insights into the Potential Health Benefits and Molecular Pharmacology. Phytomedicine 2020, 69, https://doi.org/10.1016/j.phymed.2020.153201.

11. Balboa, E.M.; Conde, E.; Moure, A.; Falqué, E.; Domínguez, H. In Vitro Antioxidant Properties of Crude Extracts and Compounds from Brown Algae. Food Chem. 2013, 138, 1764-1785, https://doi.org/10.1016/j.foodchem.2012.11.026.

12. Michalak, I.; Chojnacka, K. Algae as Production Systems of Bioactive Compounds. Eng. Life Sci. 2015, 15, 160-176, https://doi.org/10.1002/elsc.201400191.

13. Cérantola, S.; Breton, F.; Ar Gall, E.; Deslandes, E. Co-Occurrence and Antioxidant Activities of Fucol and Fucophlorethol Classes of Polymeric Phenols in Fucus Spiralis. Bot. Mar. 2006, 49, 347-351.

14. Kelman, D.; Posner, E.K.; McDermid, K.J.; Tabandera, N.K.; Wright, P.R.; Wright, A.D. Antioxidant Activity of Hawaiian Marine Algae. Mar. Drugs 2012, 10, 403-416, https://doi.org/10.3390/md10020403.

15. Harnedy, P.A.; FitzGerald, R.J. Bioactive Proteins, Peptides, And Amino Acids From Macroalgae. J. Phycol. 2011, 47, 218-232, https://doi.org/10.1111/j.1529-8817.2011.00969.x.

16. Ashour, M.; El-Shafei, A.A.; Khairy, H.M.; Abd-Elkader, D.Y.; Mattar, M.A.; Alataway, A.; Hassan, S.M. Effect of Pterocladia Capillacea Seaweed Extracts on Growth Parameters and Biochemical Constituents of Jew's Mallow. Agronomy 2020, 10, https://doi.org/10.3390/agronomy 10030420.

17. Sabeena Farvin, K.H.; Jacobsen, C. Phenolic Compounds and Antioxidant Activities of Selected Species of Seaweeds from Danish Coast. Food Chem. 2013, 138, 1670-1681, https://doi.org/10.1016/j.foodchem.2012.10.078.

18. Chakraborty, K.; Praveen, N.K.; Vijayan, K.K.; Rao, G.S. Evaluation of Phenolic Contents and Antioxidant Activities of Brown Seaweeds Belonging to Turbinaria Spp. (Phaeophyta, Sargassaceae) Collected from Gulf of Mannar. Asian Pac. J. Trop. Biomed. 2013, 3, 8-16, https://doi.org/10.1016/S2221-1691(13)60016-7.

19. Lajili, S.; Ammar, H.H.; Mzoughi, Z.; Amor, H.B.H.; Muller, C.D.; Majdoub, H.; Bouraoui, A. Characterization of Sulfated Polysaccharide from Laurencia Obtusa and Its Apoptotic, Gastroprotective and Antioxidant Activities. Int. J. Biol. Macromol. 2019, 126, 326-336, https://doi.org/10.1016/j.ijbiomac.2018.12.089.

20. Dobrinčić, A.; Balbino, S.; Zorić, Z.; Pedisić, S.; Bursać Kovačević, D.; Elez Garofulić, I.; DragovićUzelac, V. Advanced Technologies for the Extraction of Marine Brown Algal Polysaccharides. Mar. Drugs 2020, 18, https://doi.org/10.3390/md18030168.

21. Ouahid, E. A.; Mohamed, R.; Meryam, O.; Ali Yahya, H.S.; Latrach, L.; Soufiane, F.; Abdelhafid, C. Evaluation of the Energetic Valorization of the Lagoon and Mediterranean Algae (Caulerpa Prolifera \&amp; Corallina Elongata) by Anaerobic Digestion. Sci. African 2019, 5, https://doi.org/10.1016/j.sciaf.2019.e00111.

22. Lee, J.-C.; Hou, M.-F.; Huang, H.-W.; Chang, F.-R.; Yeh, C.-C.; Tang, J.-Y.; Chang, H.-W. Marine Algal Natural Products with Anti-Oxidative, Anti-Inflammatory, and Anti-Cancer Properties. Cancer Cell Int. 2013, 13, https://doi.org/10.1186/1475-2867-13-55.

23. Sarangi, M.K.; Rao, M.E.B.; Parcha, V.; Yi, D.K.; Nanda, S.S. Marine Polysaccharides for Drug Delivery in Tissue Engineering. In: Natural Polysaccharides in Drug Delivery and Biomedical Applications. Elsevier, 2019; pp. 513-530, https://doi.org/10.1016/B978-0-12-817055-7.00022-4.

24. Kang, S.M.; Cha, S.H.; Ko, J.Y.; Kang, M.C.; Kim, D.; Heo, S.J.; Kim, J.S.; Heu, M.S.; Kim, Y.T.; Jung, W.K.; Jeon, Y.J. Neuroprotective Effects of Phlorotannins Isolated from a Brown Alga, Ecklonia Cava, against H2O2-Induced Oxidative Stress in Murine Hippocampal HT22 Cells. Environ. Toxicol. Pharmacol. 2012, 34, 96-105, https://doi.org/10.1016/j.etap.2012.03.006.

25. Custodio, L.; Silvestre, L.; Rocha, M.I.; Rodrigues, M.J.; Vizetto-Duarte, C.; Pereira, H.; Barreira, L.; Varela, J. Methanol Extracts from Cystoseira Tamariscifolia and Cystoseira Nodicaulis Are Able to Inhibit Cholinesterases and Protect a Human Dopaminergic Cell Line from Hydrogen Peroxide-Induced Cytotoxicity. Pharm. Biol. 2016, 54, 1687-1696, https://doi.org/10.3109/13880209.2015.1123278.

26. Eren, B.; Tuncay Tanrıverdi, S.; Aydın Köse, F.; Özer, Ö. Antioxidant Properties Evaluation of Topical 
Astaxanthin Formulations as Anti-Aging Products. J. Cosmet. Dermatol. 2019, https://doi.org/10.1111/jocd.12665.

27. Pereira, L. Seaweeds as Source of Bioactive Substances and Skin Care Therapy-Cosmeceuticals, Algotheraphy, and Thalassotherapy. Cosmetics 2018, 5, https://doi.org/10.3390/cosmetics5040068.

28. Moujahid, A.; Bencharki, B.; Hilali, L.; Bagri, A.; Najim, L. Activités Antibactérienne et Antifongique Des Extraits d' Algues Marines d' Origine Marocaine. Biol. Santé 2004, 4, 288-305.

29. Karpiński, T.M.; Adamczak, A. Fucoxanthin-An Antibacterial Carotenoid. Antioxidants 2019, 8, https://doi.org/10.3390/antiox8080239.

30. Pinteus, S.; Silva, J.; Alves, C.; Horta, A.; Thomas, O.; Pedrosa, R. Antioxidant and Cytoprotective Activities of Fucus Spiralis Seaweed on a Human Cell in Vitro Model. Int. J. Mol. Sci. 2017, 18, https://doi.org/10.3390/ijms18020292.

31. Grina, F.; Ullah, Z.; Kaplaner, E.; Moujahid, A.; Eddoha, R.; Nasser, B.; Terzioğlu, P.; Yilmaz, M.A.; Ertaş, A.; Öztürk, M.; Essamadi, A. In Vitro Enzyme Inhibitory Properties, Antioxidant Activities, and Phytochemical Fingerprints of Five Moroccan Seaweeds. South African J. Bot. 2020, 128, 152-160, https://doi.org/10.1016/j.sajb.2019.10.021.

32. Thomes, P.; Rajendran, M.; Pasanban, B.; Rengasamy, R. Cardioprotective Activity of Cladosiphon Okamuranus Fucoidan against Isoproterenol Induced Myocardial Infarction in Rats. Eur. J. Integr. Med. 2010, 18, 52-57, https://doi.org/10.1016/j.phymed.2010.06.006.

33. Sauvant, M.; Pepin, D.; Piccini, E. Tetrahymena Pyriformis: A Tool for Toxicological Studies. Science 1999, 38, 1631-1669, https://doi.org/10.1016/s0045-6535(98)00381-6.

34. Slinkard, K.; Singleton, V.L. Total Phenol Analysis: Automation and Comparison with Manual Methods. Am. J. Enol. Vitic. 1977, 28, 49-55.

35. Tel, G.; Apaydın, M.; Duru, M.E.; Ozturk, M. Antioxidant and Cholinesterase Inhibition Activities of Three Tricholoma Species with Total Phenolic and Flavonoid Contents: The Edible Mushrooms from Anatolia. Food Anal. Methods 2012, 5, 495-504, https://doi.org/10.1007/s12161-011-9275-4.

36. Oyaizu, M. Studies on Products of Browning Reaction. Antioxidative Activities of Products of Browning Reaction Prepared from Glucosamine. Japanese J. Nutr. Diet. 2011, 44, 307-315, https://doi.org/10.5264/eiyogakuzashi.44.307.

37. Blois, M.S. Antioxidant Determinations by the Use of a Stable Free Radical. Nature 1958, 181, 11991200, https://doi.org/10.1038/1811199a0.

38. Re, R.; Pellegrini, N.; Proteggente, A.; Pannala, A.; Yang, M.; Rice-Evans, C. Antioxidant Activity Applying an Improved ABTS Radical Cation Decolorization Assay. Free Radic. Biol. Med. 1999, 26 , 1231-1237, https://doi.org/10.1016/S0891-5849(98)00315-3.

39. Nicolau, A.; Dias, N.; Mota, M.; Lima, N. Trends in the Use of Protozoa in the Assessment of Wastewater Treatment. Res. Microbiol. 2001, 152, 621-630, https://doi.org/10.1016/S0923-2508(01)01241-4.

40. Lizard, G.; Gueldry, S.; Deckert, V.; Gambert, P.; Lagrost, L. Evaluation of the Cytotoxic Effects of Some Oxysterols and of Cholesterol on Endothelial Cell Growth: Methodological Aspects. Volume 45, 1997.

41. Aebi, H. Catalase in Vitro. Methods Enzymol. 1984, 105, 121-126, https://doi.org/10.1016/s00766879(84)05016-3.

42. Paoletti, F.; Aldinucci, D.; Mocali, A.; Caparrini, A. A Sensitive Spectrophotometric Method for the Determination of Superoxide Dismutase Activity in Tissue Extracts. Anal. Biochem. 1986, 154, 536541, https://doi.org/10.1016/0003-2697(86)90026-6.

43. Sun, Y.; Oberley, L.; Li, V. A Simple Method for ClinicalAssay of Superoxide Dismutase. Clin. Chem. 1988, 34, 497-500.

44. Flohe, L.; Gunzler, W.A. Assays of Glutathione Peroxidase. Methods Enzymol. 1984, 105, 114-120, https://doi.org/10.1016/s0076-6879(84)05015-1.

45. Ellman, G.L. Tissue Sulfhydryl Groups. Am. J. Anal. Chem. 1959, 82, 70-77, https://doi.org/10.1016/0003-9861(59)90090-6.

46. Ohkawa, H.; Ohishi, N.; Yagi, K. Assay for Lipid Peroxides in Animal Tissues by Thiobarbituric Acid Reaction. Anal. Biochem. 1979, 95, 351-358, https://doi.org/10.1016/0003-2697(79)90738-3.

47. Lowry, O.H.; Rosbrough, N.J.; Farr, A.L.; Randall, R.J. Protein Measurement with the Folin Phenol Reagent. J. Biol. Chem. 1951, 193, 265-275.

48. Pinteus, S.; Silva, J.; Alves, C.; Horta, A.; Fino, N.; Rodrigues, A.I.; Mendes, S.; Pedrosa, R. Cytoprotective Effect of Seaweeds with High Antioxidant Activity from the Peniche Coast (Portugal). Food Chem. 2017, 218, 591-599, https://doi.org/10.1016/j.foodchem.2016.09.067.

49. Chernane, H.; Mansori, M.; Latique, S.; Kaoua, M.E. Evaluation of Antioxidant Capacity of Methanol Extract and Its Solvent Fractions Obtained from Four Moroccan Macro Algae Species. Eur. Sci. J. 2014, 10, 35-48.

50. Zilberg, D.; Sinai, T. Optimization and Validation of a Colorimetric Assay for Tetrahymena Sp. Survival. Res. Microbiol. 2006, 157, 355-359, https://doi.org/10.1016/j.resmic.2005.09.012.

51. Gupta, K.K.; Mishra, A.; Tiwari, A. Production of Reactive Oxygen Species, Its Effect, Drugs and Plant Extract Used as an Antioxidant, Chelator on Thalassemic Patient: A Review. Int. J. Pharm. Sci. Res. 2011, 2, 2278-2285, http://dx.doi.org/10.13040/IJPSR.0975-8232.2(9).2278-85. 
52. Marinova, E.M.; Yanishlieva, N.V. Antioxidative Activity of Extracts from Selected Species of the Family Lamiaceae in Sunflower Oil. Food Chem. 1997, 58, 245-248, https://doi.org/10.1016/S03088146(96)00223-3.

53. Zhou, K.; Yu, L. Effects of Extraction Solvent on Wheat Bran Antioxidant Activity Estimation. LWT Food Sci. Technol. 2004, 37, 717-721, https://doi.org/10.1016/j.lwt.2004.02.008.

54. Murugan, K.; Iyer, V.V. Antioxidant and Antiproliferative Activities of Extracts of Selected Red and Brown Seaweeds from the Mandapam Coast of Tamil Nadu. J. Food Biochem. 2014, 38, 92-101, https://doi.org/10.1111/jfbc.12029.

55. Jimenez-Escrig, A.; Jimenez-Jimenez, I.; Raquel, P.; Saura-calixto, F. Antioxidant Activity of Fresh and Processed Edible Seaweeds. J. Sci. Food Agric. 2001, 81, 530-534, https://doi.org/10.1002/jsfa.842.

56. O’Sullivan, A.M.; O’Callaghan, Y.C.; O’Grady, M.N.; Queguineur, B.; Hanniffy, D.; Troy, D.J.; Kerry, J.P.; O'Brien, N.M. In Vitro and Cellular Antioxidant Activities of Seaweed Extracts Prepared from Five Brown Seaweeds Harvested in Spring from the West Coast of Ireland. Food Chem. 2011, 126, 10641070, https://doi.org/10.1016/j.foodchem.2010.11.127.

57. Hayes, M.; Tierney, M.S.; Soler-Vila, A.; Croft, A.K. Activity of the Brown Macroalgae Fucus Spiralis Linnaeus Harvested from the West Coast of Irelan Antioxidantd. Curr. Res. J. Biol. Sci. 2013.

58. Shanab, S.M.M.; Shalaby, E.A.; El-Fayoumy, E.A. Enteromorpha Compressa Exhibits Potent Antioxidant Activity. J. Biomed. Biotechnol. 2011, 2011, 1-11, https://doi.org/10.1155/2011/726405.

59. Mole Megha, N.; Sabale Anjali, B. Antioxidant Potential of Seaweeds from Kunakeshwar along the West Coast Maharashtra. Asian J. Biomed. Pharm. Sci. 2013, 3, 45-50.

60. Yuan, Y.V.; Carrington, M.F.; Walsh, N.A. Extracts from Dulse (Palmaria Palmata) Are Effective Antioxidants and Inhibitors of Cell Proliferation in Vitro. Food Chem. Toxicol. 2005, 43, 1073-1081, https://doi.org/10.1016/j.fct.2005.02.012.

61. Andrade, P.B.; Barbosa, M.; Matos, R.P.; Lopes, G.; Vinholes, J.; Mouga, T.; Valentão, P. Valuable Compounds in Macroalgae Extracts. Food Chem. 2013, 138, 1819-1828, https://doi.org/10.1016/j.foodchem.2012.11.081.

62. Audibert, L.; Fauchon, M.; Blanc, N.; Hauchard, D.; Ar Gall, E. Phenolic Compounds in the Brown Seaweed Ascophyllum Nodosum: Distribution and Radical-Scavenging Activities. Phytochem. Anal. 2010, 21, 399-405, https://doi.org/10.1002/pca.1210.

63. Nanney, D.L.; Simon, E.M. Chapter-1 Laboratory and Evolutionary History of Tetrahymena Thermophila. In: Methods in Cell Biology. Volume 62, 1999; pp 3-25, https://doi.org/10.1016/S0091679X(08)61527-7.

64. Rachida, C.; Khadija, M.; Fadila, A.; Abdelaziz, S. Protective and Antioxidant Potential of the Argan Oil on Induced Oxidative Stress in Tetrahymena Pyriformis. J. Med. Plants Res. 2013, 7, 1961-1968, https://doi.org/10.5897/JMPR12.139.

65. Errafiy, N.; Ammar, E.; Soukri, A. Protective Effect of Some Essential Oils against Oxidative and Nitrosative Stress on Tetrahymena Thermophila Growth. J. Essent. Oil Res. 2013, 25, 339-347, https://doi.org/10.1080/10412905.2013.775681.

66. Mar, P.D.; Khalfi, B.El; Soukri, A.; Nandi, N.; Sen, A.; Banerjee, R.; Kumar, S.; Kumar, V.; Ghosh, A.N.; Das, P.; Lee, J.S.; Kim, Y.R.E.; Park, J.M.; Ha, S.; Kim, Y.R.E.; Baek, N.I.; Hong, E.K.; Cells, H.; Farmani, F.; Sabahi, Z.; Ramdani, M.M.; Elasri, O.; Saidi, N.; Elkhiati, N.; Taybi, F.A.; Mostareh, M.; Zaraali, O.; Haloui, B.; Ramdani, M.M.; Ohkawa, H.; Ohishi, N.; Yagi, K.; Nozawa, Y.; Thompson, G.U.Y.A.; Niehus, L.; Henniges, U.; Horsky, M.; Prohaska, T.; Potthast, A.; Brückle, I.; Symons, M.C.R.; Rusakiewicz, S.; Rees, R.C.; Ahmad, S.I.; Robertson, R.; Guihéneuf, F.; Bahar, B.; Schmid, M.; Stengel, D.; Fitzgerald, G.; Ross, R.; Stanton, C. The Anti-Inflammatory Effect of Algae-Derived Lipid Extracts on Lipopolysaccharide (LPS)-Stimulated Human THP-1 Macrophages. Mar. Drugs 2018, 13, 5402-5424, https://doi.org/10.3390/md13085402.

67. Thomas, N.; Kim, S. Beneficial Effects of Marine Algal Compounds in Cosmeceuticals. Mar. Drugs 2013, 11, 146-164, https://doi.org/10.3390/md11010146.

68. Wang, T.; Jónsdóttir, R.; Liu, H.; Gu, L.; Kristinsson, H. G.; Raghavan, S.; Olafsdóttir, G. Antioxidant Capacities of Phlorotannins Extracted from the Brown Algae Fucus Vesiculosus. J. Agric. Food Chem. 2012, 60, 5874-5883, https://doi.org/10.1021/jf3003653.

69. Elbaz, A.; Wei, Y. Y.; Meng, Q.; Zheng, Q.; Yang, Z.M. Mercury-Induced Oxidative Stress and Impact on Antioxidant Enzymes in Chlamydomonas Reinhardtii. Ecotoxicology 2010, 19, 1285-1293, https://doi.org/10.1007/s10646-010-0514-z.

70. Boya, P.; Pefia, D.; Beloqui, O.; Larrea, E.; Civeira, M.; Prieto, J. Mononuclear Cells from Patients with Chronic Hepatitis C. J. Hepatol. 1999, 31, 808-814.

71. Pinteus, S.; Silva, J.; Alves, C.; Horta, A.; Thomas, O.; Pedrosa, R. Antioxidant and Cytoprotective Activities of Fucus Spiralis Seaweed on a Human Cell in Vitro Model. Int. J. Mol. Sci. 2017, 18, https://doi.org/10.3390/ijms18020292.

72. Sies, H. Hydrogen Peroxide as a Central Redox Signaling Molecule in Physiological Oxidative Stress: Oxidative Eustress. Redox Biol. 2017, 11, 613-619, https://doi.org/10.1016/j.redox.2016.12.035.

73. Perkins, C.L.; Fang, G.; Kim, C.N.; Bhalla, K.N. The Role of Apaf-1, Caspase-9, and Bid Proteins in 
Etoposide- or Paclitaxel-Induced Mitochondrial Events during Apoptosis. Cancer Res. 2000, 60, 16451653.

74. Goldstein, J.C.; Waterhouse, N.J.; Juin, P.; Evan, G.I.; Green, D.R. The Coordinate Release of Cytochrome : C: During Apoptosis Is Rapid, Complete and Kinetically Invariant. Nat. Cell Biol. 2000, 2, 156-162, https://doi.org/10.1038/35004029.

75. Krause, M.; Durner, D. Harpin Inactivates Mitochondria in Arabidopsis Suspension Cells. Mol. PlantMicrobe Interact. 2004, 17, 131-139, https://doi.org/10.1094/MPMI.2004.17.2.131. 